\title{
A maternidade como resistência à violência de Estado*
}

\author{
Vinicius Santiago**
}

\section{Resumo}

Este trabalho analisa o movimento de mães que perderam seus filhos, assassinados por policiais militares nas favelas do Rio de Janeiro, como um dos efeitos perversos da política de pacificação das favelas. A luta das mães pela responsabilização e pelo reconhecimento do Estado brasileiro pelas mortes de seus filhos as inscreve em um movimento que mobiliza a maternidade como símbolo central para o engajamento político. É sobre os limites e ambivalências da maternidade que as mães mobilizam as condições para catalisar um espaço de aliança e resistência. A violência perpetrada sobre os filhos também atinge essas mulheres, cujos corpos maternos se tornam protagonistas no enfrentamento à violência de Estado.

Palavras-chave: Mães, Maternidade, Corpo, Violência, Estado.

\footnotetext{
* Recebido em 02 de abril de 2017, aceito em 11 de abril de 2018. Agradeço, primeiramente, ao movimento de mães e familiares de vítimas da violência de Estado, no Rio de Janeiro, cuja luta por justiça tenho acompanhado de perto nos últimos anos, pela interlocução e pelo que tenho aprendido. Agradeço também a Marta Fernández, Carla Rodrigues e James Casas Klausen pelas riquíssimas contribuições, aos colegas do Instituto de Relações Internacionais da PUC-Rio pelas importantes observações feitas em um seminário de pesquisa no qual este texto foi apresentado. E, por fim, agradeço aos pareceristas anônimos pelo trabalho cuidadoso, pedagógico e estimulante com meu texto.

** Doutorando em Relações Internacionais no Instituto de Relações Internacionais, Pontíficia Universidade Católica do Rio de Janeiro (Puc-RJ), Rio de Janeiro, RJ, Brasil. viniciuswbsantiago@gmail.com / https://orcid.org/00000002-7328-9461.
} 
Motherhood as Resistance to State Violence

\begin{abstract}
This paper analyzes the political movement of mothers whose children were killed by military police in the slums of Rio de Janeiro, one of the most perverse effects of the favela pacification program. The mothers' claim for justice to the Brazilian state due to their children's deaths mobilizes motherhood as a central symbol for political engagement. Within the limits and ambivalences of motherhood the mothers catalyze a space of alliance and resistance. The violence perpetrated on their sons also affects these women whose maternal bodies become key agents in the confrontation of state violence.
\end{abstract}

Keywords: Mothers, Motherhood, Body, Violence, State. 


\section{Introdução}

Ao longo do século XX, a cidade do Rio de Janeiro foi sendo lida a partir de um discurso que identifica alguns territórios da cidade, a saber, as favelas, como territórios associados a marginalidade, pobreza e criminalidade (Valladares, 2005). Os moradores de favelas são reconhecidos, dessa forma, por uma leitura radical de alteridade em que se constituem como o "outro" da cidade, lidos a partir da chave da diferença, perigosa $e$ ameaçadora da ordem social que deve ser controlada $e$ gerenciada pelas forças estatais brasileiras.

A construção social das favelas como o território da violência na cidade atinge seu apogeu, mais especificamente, em dois momentos históricos. Conforme argumenta Márcia Leite (2012), o primeiro se deu a partir dos anos 1990 com a "promoção, por parte do Estado, de uma 'guerra' aos traficantes de drogas ali sediados", e o segundo com a implantação, a partir de 2008, das Unidades de Polícia Pacificadora (UPPs) "com o objetivo de retomar o controle armado desses territórios $e$ 'civilizar' seus moradores como condição para a integração desses territórios à cidade" (Leite, 2012:374).

Segundo dados apresentados no Atlas da Violência (Cerqueira et alii, 2017), estudo realizado pelo IPEA em parceria com o Fórum Brasileiro de Segurança Pública em 2017, o Brasil registrou 59.080 homicídios em 2015, sendo que a cada 100 pessoas assassinadas no Brasil, 71 são negras. $O$ perfil predominante das vítimas de violência policial no Brasil - segundo o Atlas, os negros possuem chances $23,5 \%$ maiores de serem assassinados em relação a brasileiros de outras raças - revela os desafios enfrentados pela população favelada no que diz respeito ao direito à vida. Casos como o de Lucinda, cujo filho foi assassinado no Complexo do Alemão enquanto brincava à porta 
de casa, revelam o estado de insegurança e suspensão do direito à vida que se impõe no dia a dia da população favelada. ${ }^{1}$

A territorialização da violência nas favelas acaba naturalizando a ideia de que favela é sinônimo de violência e que se constitui em um espaço de exceção cuja mediação pelo Estado deve se dar por meio de medidas também excepcionais, como argumenta Márcia Leite (2012), que se traduzem em invasão por tropas policiais militares, execução sumária de moradores, caracterizando aquele território como um cenário de guerra.

Uma série de episódios, como arrastões, assaltos, tiroteios, sequestros e chacinas, contribuíram para que fosse gestada uma representação do Rio de Janeiro como uma "cidade em guerra", segundo Leite (2012). Os efeitos da "metáfora da guerra" atingem não somente os traficantes de drogas, alvos da recente política de pacificação da cidade, mas também colocam em risco a vida de toda uma população específica, reverberando o medo e o terror em muitas famílias, que acabam sendo vítimas - mortas como efeito colateral, indesejável, porém inevitável, dessa guerra.

Ao longo das duas últimas décadas, inúmeros foram os casos de chacinas de jovens moradores de favela cujos corpos foram executados sumariamente por agentes do Estado ou desaparecidos, e muitos até hoje não encontrados. A título de exemplo, posso elencar alguns casos, como: a chacina de Acari, que ficou internacionalmente conhecida como o caso de desaparecimento de onze jovens da favela de Acari², em 1990; a

1 Segundo dados da Justiça Global, houve um aumento de 18,6\% de casos desse tipo até julho de 2015, em que 410 pessoas foram mortas dessa forma pela $\mathrm{PM}$, em relação ao mesmo período do ano anterior. O número de homicídios praticados por policiais militares nas favelas em 2014 já havia superado em $40 \%$ as ocorrências registradas em 2013. O mapa revela que os espaços onde a polícia mais mata são as favelas. Disponível em: http://global.org.br/programas/justicaglobal-lanca-o-site-onde-a-policia-matahomicidios-cometidos-pela-policia-militardo-rio-de-janeiro/. Acesso em 24 jan. 2016.

2 As temáticas da violência de Estado e do movimento de mães e familiares na luta por justiça já têm sido objeto de estudo de importantes trabalhos. Sugiro ver a dissertação de Fábio Araújo, Do luto à luta: a experiência das mães de Acari 
chacina da Candelária, em que oito jovens sem teto foram assassinados por policiais militares; a chacina do Borel, em 2003, na qual quatro jovens foram assassinados por policiais; a chacina de Nova Iguaçu, em 2005, que ficou conhecida como uma das maiores do estado do Rio de Janeiro em que 29 pessoas foram mortas por policiais militares; a chacina de Costa Barros, em 2015, na qual cinco jovens foram alvejados por policiais enquanto dirigiam dentro da comunidade, dentre tantos outros casos de violência de Estado.

Em meio a essa "situação de guerra" que se instala na cidade do Rio de Janeiro, as mães dos jovens assassinados acabam também sendo inscritas nessa "guerra" na medida em que, ao perderem seus filhos "pelas mãos do Estado", identificamno como aquele cujas práticas devem questionar. Ao perderem seus filhos assassinados por agentes de instituições estatais, como a Polícia Militar, as mães passam a se unir em uma luta por reparação, reconhecimento e responsabilização do Estado por esses assassinatos.

Neste artigo, trarei algumas problematizações em torno da noção de maternidade mobilizada no movimento de mães no Rio de Janeiro. Para isso, apoio-me em alguns excertos de seus discursos, tomados ao longo de pesquisa etnográfica realizada com as mães e familiares de vítimas da violência de Estado, para elucidar os limites, os entraves $e$ as potencialidades catalisados pela noção de maternidade nesse contexto de luta. A pesquisa de campo, realizada entre 2014 e 2018, teve início em meu primeiro contato com o movimento de mães e familiares em um ato público organizado na favela de Manguinhos, zona norte do Rio, em homenagem e memória a Tiago, filho de Selma, assassinado por um policial militar naquele ano. Esse ato público me levou a conhecer outras mães que também tiveram seus filhos assassinados por agentes oficiais do Estado brasileiro e que fazem parte de uma rede de apoio e solidariedade na reivindicação de

(Araújo, 2007), e a tese de Paula Lacerda, $O$ "caso dos meninos emasculados de Altamira": polícia, justiça e movimento social (Lacerda, 2012). 
justiça e na denúncia das violações de direitos humanos perpetradas "pelo Estado".

Naquele mesmo ano, conheci a Rede de Comunidades e Movimentos contra a violência do estado do Rio de Janeiro ${ }^{3}$, coletivo organizado $e$ protagonizado por mães e familiares moradores de favelas e vítimas da violência policial. Passei a frequentar esse espaço mobilizado pelo ativismo dos familiares $e$ outros apoiadores. Meu envolvimento nesse espaço de resistência, tanto no que diz respeito ao acompanhamento aproximado da luta das mães mais envolvidas diretamente na Rede quanto na minha participação em reuniões do coletivo, na organização dos eventos realizados, como atos, vigílias e caminhadas, foi tecendo a interlocução que estabeleci com elas ao longo dos últimos anos. Os discursos apresentados neste artigo são, portanto, parte de um esforço etnográfico no qual o lugar de observador-participante me permitiu compartilhar dos contextos narrativos dentro dos quais a luta dessas mulheres acontece.

Tal empreitada etnográfica traz consigo os desafios de se colocar diante de um movimento social como esse, cujo trabalho duro, doloroso e catalisador de muito sofrimento pessoal, expõe o delicado terreno sobre o qual me situo diante das experiências compartilhadas e vividas. Consciente do meu lugar ocupado nessa luta e longe de pretender silenciar os possíveis efeitos de poder implicados na minha relação com o campo, meu engajamento etnográfico se deu de modo a respeitar esse espaço protagonizado por elas e no qual as experiências de sofrimento expostas $e$ compartilhadas publicamente se caracterizam, como argumenta John Borneman (2002), como uma forma de agenciamento do processo de cura das feridas deixadas pela violência institucional. Compreender esse espaço não somente como um espaço de denúncia, mas, sobretudo, como um espaço de formação de subjetividades políticas que surgem no bojo do enfrentamento à violência de Estado produz uma demanda ética que me conduziu a algumas escolhas metodológicas.

3 Para mais informações sobre a Rede, acessar http://redecontraviolencia.org/. 
A primeira delas é a "etnografia multissituada" (Marcus, 1995), cujo principal método consiste em seguir os passos dos sujeitos (follow the subjects) a fim compreender, em uma perspectiva de campo dinâmico e multissituado, as múltiplas operações de poder que os constituem. As falas elucidadas neste artigo foram registradas em eventos públicos nos quais as mães $e$ familiares estiveram presentes, como um ato realizado em Manguinhos; um evento de homenagem às vítimas da chacina de Acari que aconteceu na Organização dos Advogados do Brasil (OAB) do Rio, ambos ocorridos no ano de 2015; e um ato em frente ao Ministério Público do Estado do Rio de Janeiro, em 2017.

A segunda escolha metodológica, e talvez a mais importante, é o testemunho como um ato de escuta (Borneman, 2002). Diante das inúmeras violências presentes em uma etnografia como esta, em que os desafios que atravessam as relações são catalisados por um campo de grande profundidade emocional, escutar o que tais atores têm a dizer se constitui em uma forma de respeito, não somente pela dureza de seu sofrimento, mas, sobretudo, porque tais atores, segundo argumenta Borneman (2002), com muito a ganhar e pouco a perder, estão dispostos a assumir grandes riscos ao se engajarem em falar a verdade ao poder, ou revelar-lhe a "sua" verdade. $\mathrm{O}$ testemunho, como ferramenta metodológica, adquire tamanha importância nesse contexto, pois é uma forma de compreender esse espaço político, não somente como um lugar do endereçamento da violência de Estado, mas também como um lugar de afeto, memória, e que garante, como argumenta a antropóloga Adriana Vianna (2014:232), um lugar social que "certos mortos e vivos merecem ocupar na cena pública, sendo reconhecidos como vítimas e não como ocorrências massivas, generalizadas e previsíveis do universo da 'guerra' interna".

A combinação metodológica de uma etnografia multissituada e o testemunho como forma de escuta permite compreender, no campo, a complexa relação entre a performatividade do gênero e do Estado. Seguindo os rastros 
deixados pelas densas análises etnográficas de Adriana Vianna $e$ Juliana Farias (2011), trarei ao longo deste artigo reflexões que permitem compreender como gênero e Estado se relacionam intimamente em um duplo fazer que se revela, nas palavras de Adriana Vianna e Laura Lowenkron (2017:49), como "processos de estatização do gênero e generificação do Estado". Partindo do pressuposto que o Estado se constitui em um espaço em constante disputa política, uma categoria contraditória, polissêmica e plural, faz-se necessário compreender como gênero e Estado estão inseridos em uma dinâmica de constituição mútua, na qual o gênero é fabricado, através da maternidade como signo marcador dessa luta política, simultaneamente ao processo de formação estatal, ao que Vianna e Lowenkron (2017:17) chamam de um "duplo fazer do gênero e do Estado".

Longe de serem categorias fixas, coesas e estáveis, "gênero" e "Estado" revelam-se como campos semânticos permanentemente instáveis e fluidos que se constituem de maneira relacional, como argumentam as autoras. A presença marcada de expressões como "violência de Estado" e "Estado", neste artigo, revela o lugar ocupado para além das categorias analíticas próprias da literatura evocada. Tais termos são tratados aqui como categorias êmicas, cuja apropriação pelo movimento de mães e familiares se insere em um terreno polissêmico que lhes permite acionar estrategicamente tais conceitos como forma de marcar suas posições diante das relações de poder que os atravessam.

As falas públicas das mães $e$ familiares vítimas da violência de Estado registradas nos contextos narrativos em que estive presente são trazidas aqui com o intuito de elucidar os limites $e$ ambivalências da maternidade como um marcador cujo significado político vai sendo construído simultaneamente ao campo semântico do Estado como instável e fluido em um processo de generificação. As vozes que trago aqui são as das mães Carmen, Dulcinéia e Selma, e de Paula, irmã de vítima da violência policial - mulheres cujas experiências de dor $e$ 
sofrimento compartilhadas publicamente tive a chance de testemunhar. ${ }^{4}$

Este artigo traz, de forma entrelaçada a essas vozes, o aporte teórico que parte do debate entre Judith Butler e Julia Kristeva sobre o lugar da maternidade no campo da filosofia da linguagem; da contribuição do pensamento feminista negro, especialmente de Patricia Hill Collins; e da importante interlocução com trabalhos que dialogam com a antropologia de Estado para entender os problemas e os perigos que circulam em torno da maternidade $e$ como esta constitui um conceito em disputa. Além disso, faço uma reflexão, a partir de Butler, sobre a condição de precariedade na qual se inserem as mães e através da qual elas catalisam uma força que compreende a precariedade como um lugar de aliança, um espaço de aparecimento criado entre elas. O corpo precário ganha, então, um significado que aciona tanto a ação quanto a reivindicação de aparecer em público, apresentando um modo de viver tanto na precariedade quanto no direito de resistir e de realizar o luto público.

\section{A maternidade como um signo em disputa}

Boa noite a todos, para quem não me conhece, eu sou Carmen, mãe do Pedro. E infelizmente o mesmo Estado que me abandonou quando eu cresci, infelizmente esse mesmo Estado que um dia eu acreditei, foi o mesmo Estado que torturou e matou meu filho Pedro no dia $1^{\circ}$ de janeiro de 2008 (fala de Carmen, mãe de Pedro, ênfase do autor).

4 Optei neste artigo por trocar os nomes de mães e familiares, bem como dos jovens assassinados, a fim de preservar a identidade de tais interlocutoras e como forma de proteger, em alguns casos, seus respectivos processos judiciais em andamento. Adotei a mesma estratégia de ocultamento para todos os casos, mesmo aqueles de maior notoriedade pública. No texto, os nomes próprios ficcionalizados estão em itálico. A única exceção em que mantenho os nomes reais é o caso de falecimento de Joselita após a perda de seu filho Roberto, assassinado na chacina de Costa Barros, caso repercutido na mídia (ver nota 11) e que não fez parte, todavia, do meu campo etnográfico. 
Essa é a fala de Carmen $^{5}$, mãe de vítima da violência de Estado, durante um ato público na favela de Manguinhos em 2015. Como podemos observar no trecho destacado, o uso do significante "mãe" é recorrente por parte daquelas que reivindicam a responsabilização e o reconhecimento "do Estado" pelo assassinato de seus filhos. A categoria "mãe" se apresenta como um atributo muito peculiar a essa luta, pois possui um peso ontológico que garante a essas mulheres um caráter político em um processo de subjetivação e visibilização de seus corpos no domínio público. Sua presença em atos, vigílias e caminhadas constitui-se em uma forma de mobilizar a opinião pública, a mídia $e$ autoridades para a legitimidade de sua reivindicação.

A categoria "mãe" vem aliada a uma outra, "vítima", que surge no bojo da luta por direitos e está inscrita em um processo de subjetivação atravessado, como argumenta Adriana Vianna, pela reinvenção do corpo materno que se torna suporte para uma

linguagem não apenas da perda insuportável, mas também dos processos de reinscrição de si no mundo e do próprio mundo como algo que agora precisa ganhar novo sentido $e$ que passa a ser lido e descrito em outros termos (Vianna, 2014:232).

Chegar aos atos públicos apresentando-se como "mãe" $e$ trazer, em seus corpos, a camiseta estampada com a fotografia de seus filhos e cartazes com seus nomes se constituem formas estratégicas de agenciar processos políticos por meio da

5 O filho de Carmen, Pedro, foi assassinado nas dependências do Departamento Geral de Ações Sócio Educativas (DEGASE) por agentes do Estado que o torturaram até a morte. Segundo a mãe, um dos agentes trabalha na UPP de Manguinhos, local onde ocorreu o ato. O DEGASE é um órgão do Governo do Estado do Rio de Janeiro que executa as medidas judiciais aplicadas aos adolescentes que cometeram atos infracionais. Pedro já havia passado pelo sistema socioeducativo duas vezes antes de ter voltado e ter sido torturado até a morte, segundo as narrativas apresentadas pela mãe. Em suas falas públicas, Carmen define, recorrentemente, o sistema socioeducativo como um sistema sociotortura. 
ressignificação do corpo materno como sendo ele mesmo a própria denúncia à violência de Estado. ${ }^{6}$

No contexto em questão, a maternidade é o elemento sobre o qual se apoia toda a legitimidade da luta e, segundo Rita Freitas (2002), é por intermédio da maternidade que as mães se fazem sujeitos visíveis na política. Elas conferem à maternidade outro significado que lhes possibilita a inclusão no mundo público. Historicamente, a maternidade é atrelada a um bem maior em nossa sociedade, um valor supremo e que traz consigo a ideia de uma mãe sofredora, a mãe "que chora, que sofre, que tem o avental 'todo sujo de ovo', que 'padece no paraíso', a 'rainha do lar', que se sacrifica pelos filhos, a compadecida que tudo perdoa; enfim, que os ama acima de tudo" (Freitas, 2002:80).

Em meu percurso etnográfico, pude perceber que essa figura da mater dolorosa se fazia muito presente nas falas das mães, afinal, é em torno da dor pela perda do filho que essas mulheres se reconstroem $e$ dão um novo significado a suas vidas. Além de serem mobilizadas pela figura da dor, elas reproduzem uma ideia de maternidade que gira em torno do "amor materno" como catalisador da luta. Esse comportamento revela que todas elas compartilham entre si o sentimento de serem movidas pelo "amor de mãe" e, a partir desse amor, formam uma rede de solidariedade. É comum entre as mães, ao fazerem referência à dor que sentem pela perda do filho, sugerir que sentem a dor como se fosse em seu próprio corpo, fazendo uma alusão ao fato de esses filhos terem saído de dentro delas. Essa "dor de mãe" sugere, portanto, uma ligação mais que afetiva e de amor, mas umbilical.

Julia Kristeva afirma, em seu artigo Stabat Mater (1985), que o leite e as lágrimas são os signos por excelência da mater dolorosa, que invade o ocidente no século XI e alcança seu auge

6 Para uma reflexão mais aprofundada sobre a questão da vítima/vitimização de atores em processos políticos de reparação e reconhecimento ver Das (2008a), La antropologia del dolor, Sarti (2011), A vítima como figura contemporânea; e Jimeno (2010) Emoçôes e Política: a vítima e a construção de comunidades emocionais. 
no XIV. Para a autora, a imagem da mãe sofredora é derivada de uma longa tradição na qual o feminino é pensado sob o constructo simbólico do cristianismo e, daí, sob a figura maternal. Essa representação da figura da mãe carrega consigo atributos de sofrimento, e o que o leite e as lágrimas têm em comum é que ambos são metáforas da não linguagem, de um "semiótico" que não coincide com a comunicação linguística. Nesse sentido, a figura da mater dolorosa, segundo a autora, situa-se em um terreno onde não lhe é possivel fazer uso da linguagem, da fala, restando-lhe somente as lágrimas.

Para Kristeva, o corpo materno é portador de um conjunto de significados anteriores à própria cultura e está inserido em uma economia libidinal pré-discursiva em que os impulsos libidinais primários (como, por exemplo, a dependência radical da criança com o corpo materno) emergem em seus significados múltiplos. Entretanto, a leitura que Judith Butler faz do pensamento de Kristeva nos indica que a manifestação dessas pulsões múltiplas só é possível no campo do "semiótico"; a rigor, nessa dimensão da linguagem ocasionada pelo corpo materno primário, na qual a multiplicidade libidinal original se expressa $e$ onde prevalecem os significados múltiplos e a semântica em aberto. Já o campo do simbólico se constituiria em uma significação linguística (assim como o semiótico), mas que, no entanto, recalca os impulsos primários e repudia o relacionamento primário com o corpo materno (Butler, 2016a).

O campo do simbólico é estruturado em torno da lei paterna como princípio organizador universal da própria cultura e expressa uma linguagem que organiza o mundo pela supressão de múltiplos significados, na qual as pulsões maternas não teriam lugar. Para Kristeva, segundo a leitura de Butler, o corpo materno só poderia se manifestar, então, na linguagem poética, sob domínio do semiótico, por possuir sua própria modalidade de sentido e revelar uma heterogeneidade irreprimível de sons $e$ significados múltiplos que não se conformariam às exigências da designação unívoca e repressora do simbólico (Butler, 2016a). "A linguagem poética indica sempre um retorno ao terreno materno, 
em que o materno tanto significa dependência libidinal como a heterogeneidade das pulsões" (Butler, 2016a:149).

Para Kristeva (1984), enquanto, na modalidade simbólica, a linguagem repousa no corte da relação de dependência materna e recalca a pulsão instintiva com a mãe abstraindo a maternidade da materialidade da linguagem, na modalidade semiótica, a linguagem resgata o corpo materno, rompe, desloca e subverte a lei paterna. Entretanto, para Butler, essa formulação é um fracasso na medida em que:

se o simbólico e o semiótico são entendidos como duas modalidades de linguagem, e se se compreende que o semiótico é geralmente reprimido pelo simbólico, então, para Kristeva, a linguagem é entendida como um sistema em que o simbólico permanece hegemônico, exceto quando o semiótico rompe ou perturba seu processo significante por via da elisão, repetição, sons isolados $e$ multiplicações de significados, por meio de imagens $e$ metáforas indefinidamente significantes (Butler, 2016a:147).

A crítica de Butler ao projeto político-filosófico de Kristeva vai na direção de tensionar os limites entre o semiótico e o simbólico na medida em que, por mais que Kristeva afirme que o semiótico possa subverter e deslocar o simbólico, permitindo assim que as pulsões primárias maternas possam se expressar em sua linguagem heterogênea e múltipla, o semiótico permanece inevitavelmente dentro ou abaixo do território da lei paterna. Butler vai mais além e defende que Kristeva acaba por apropriar acriticamente a teoria da pulsão e reinstala a lei paterna no domínio do semiótico. Além disso, Butler defende que, ao localizar o corpo materno no terreno do semiótico - cujo status ontológico é anterior à linguagem -, Kristeva acaba por delimitar a maternidade como uma realidade essencialmente pré-cultural, enquanto a noção de cultura permanece como uma estrutura paterna. Ou seja, ao subordinar o semiótico ao simbólico, Kristeva reforçaria o domínio da lei paterna sobre o corpo materno e 
reificaria a maternidade negando as possibilidades e significados variados da maternidade como prática cultural.

Fanny Söderbäck, em seu artigo Motherhood: a site of repression or liberation?, argumenta que Butler interpreta equivocadamente um aspecto central do trabalho de Kristeva que, a rigor, a diferencia de Lacan. Segundo Söderbäck (2010), o semiótico, para Kristeva, é tanto condição para quanto produto do simbólico:

\begin{abstract}
Embora originalmente uma pré-condição do simbólico, o semiótico funciona dentro de práticas significantes como o resultado de uma transgressão do simbólico. Portanto, o semiótico que 'precede' a simbolização é somente uma suposição teórica justificada pela necessidade da descrição. Ele existe na prática somente dentro do simbólico e requer a quebra do simbólico para obter a articulação complexa que nós associamos com ele em práticas poéticas e musicais (Kristeva apud Söderbäck, 2010:6).
\end{abstract}

Em Revolution in Poetic Languages, Kristeva afirma que o semiótico "já é sempre social e, portanto, histórico" (Kristeva, 1984:68) e é "inevitável e inseparavelmente simbólico" (Kristeva, 1984:96). Nesse sentido, não há possibilidade de negar completamente o simbólico, como Butler parece esperar de Kristeva. Contrariamente à crítica de Butler, Söderbäck (2010) afirma que Kristeva não pretende recusar o simbólico e que tampouco almeja a emancipação, mas sim a subversão como uma forma de transformação.

Entretanto, a crítica de Butler às formulações filosóficas de Kristeva segue contundente no que diz respeito à maternidade. Butler defende que Kristeva não leva em conta a dimensão da construção cultural compulsória do corpo feminino como um corpo essencialmente materno. Partindo de uma perspectiva foucaultiana, Butler (2016a:162) sugere em Problemas de Gênero que 
o corpo não é "sexuado" em nenhum sentido significativo antes de sua determinação num discurso pelo qual ele é investido de uma "ideia" de sexo natural ou essencial. $\mathrm{O}$ corpo ganha significado no discurso no contexto das relações de poder.

Partindo desse ponto, a autora segue sua crítica afirmando que:

Enquanto ela [Kristeva] postula um corpo materno anterior ao discurso, o qual exerce sua própria força causal na estrutura das pulsões, Foucault argumentaria sem dúvida que a produção discursiva do corpo materno como prédiscursivo é uma tática de autoampliação e ocultação das relações de poder específicas pelas quais o tropo do corpo materno é produzido. Nesses termos, o corpo materno não seria mais entendido como a base oculta de toda significação, causa tácita de toda a cultura. Ao invés disso, o seria como efeito ou consequência de um sistema de sexualidade em que se exige do corpo feminino que ele assuma a maternidade como essência do seu eu e lei de seu desejo (Butler, 2016a:162).

O debate entre Judith Butler e Julia Kristeva acerca do lugar da maternidade assume uma importante função no campo da filosofia da linguagem $e$ dos estudos de gênero, pois apresenta a maternidade como um lugar em constante disputa. Se por um lado, a maternidade passa a ser um elemento combatido com veemência por certa vertente pós-estruturalista assumida por Butler e que parte do pensamento foucaultiano como crítica à essencialização da maternidade como um atributo natural da mulher, cujos efeitos de poder apagam seu caráter historicamente compulsório, por outro, a maternidade é um lugar revisitado por Kristeva que a identifica como um potencial subversivo das estruturas linguísticas em torno das quais a própria maternidade é construída.

$\mathrm{O}$ movimento de retorno de Kristeva à maternidade apresenta possibilidades de transgredir a própria estrutura de significação simbólica dentro da qual a maternidade se constrói 
sem, no entanto, desvencilhar-se dessa estrutura linguística que a autora identifica como aquela que recalca as pulsões primárias maternas. Se para Butler, o retorno à maternidade pode parecer um retrocesso político, para Kristeva tal retorno indica não uma reafirmação da condição submissa da maternidade à estrutura de significação simbólica, mas sim como um lugar sem o qual o simbólico não existe e que, portanto, apresenta as condições de transgredi-lo ressignificando, assim, as condições dentro das quais a maternidade pode ser apreendida.

Apesar de tal debate ser fundamental para o desenvolvimento de meu argumento neste artigo, os termos dentro dos quais ele apresenta a maternidade são insuficientes para analisar os contextos etnográficos de violência extrema em que tenho me engajado. Observar a maternidade pelo prisma do debate entre Butler e Kristeva de modo a encará-la ou como lugar repressivo ou como lugar de emancipação não satisfaz a complexidade que a noção de maternidade assume no contexto do movimento de mães do Rio de Janeiro. Entretanto, apesar de insuficiente, tal debate se faz fundamental para apontar os caminhos possíveis de transformação da maternidade em um signo político da luta de mães. De tal forma, neste artigo, meu movimento é tanto o de pensar com Butler e Kristeva como para além delas, pois no contexto etnográfico no qual meu situo a maternidade não só é revelada em seu caráter politicamente agenciador - distanciando-se, pois, da crítica de Butler - como transcende o domínio da não linguagem - como defende Kristeva - $e$ atinge, publicamente, seus efeitos perturbadores da estrutura do simbólico e reveladores da violência que nele opera.

No contexto do movimento de mães das favelas do Rio de Janeiro, nota-se que a noção de maternidade que é mobilizada centra-se justamente na ideia de uma maternidade essencializada, que passa pela naturalização do corpo feminino como um corpo materno, um corpo de mãe que fala pelo seu filho e que sente a dor do filho. 
Nossos mortos têm voz, nossos filhos têm voz, nós mães temos que gritar, porque nós demos à luz, isso nós não podemos esquecer. [...] Nós carregamos eles em nossas barrigas, nós demos à luz, nós demos a vida e isso nós não vamos esquecer. Como eles [os policiais, o Estado] ousam negar que a gente fale o nome de nossos filhos? [...] Por que eles querem arrancar esse pedaço de nós? Não esqueceremos essa parte amputada, essa dor que dói como uma fisgada, do membro que já não existe mais. Se querem secar nossas lágrimas, se querem que nossos mortos virem comida de saúva, é nosso dever não deixar! (fala da mãe Dulcinéia, em ato na favela de Manguinhos em 2015, ênfase do autor).

O atributo da pulsão primária materna que Kristeva mobiliza em suas formulações teórico-filosóficas pode ser esmiuçado no discurso de Dulcinéia que o revela ao fazer referência ao corpo materno como aquele que dá à luz, que gera a vida. A fala de Dulcinéia sugere que o laço que liga mãe e filho se constitui em um signo que é destruído pela intervenção da violência de Estado em sua vida íntima da forma mais violenta e perversa.

Avançando a partir da reflexão de Kristeva acerca da relação entre o semiótico e o simbólico no contexto da fala de Dulcinéia, é como se, em última instância, o Estado estivesse representado pelo domínio linguístico do simbólico e recalcasse o relacionamento primário do filho com o corpo materno e, consequentemente, abstraísse a maternidade da materialidade $e$ do campo da linguagem. Nesse caso, o domínio do simbólico, estruturado em torno da lei paterna como princípio organizador universal, e representado pelo Estado em sua complexidade institucional (a polícia, o Judiciário, a mídia), estaria suprimindo o campo do semiótico, no qual os corpos maternos dessas mulheres que vão a publico ganham um novo significado político.

Diante da violência do corte, da interrupção no laço entre mãe $e$ filho, não parece restar às mães outra opção a não ser a revolta e a indignação por ter "o Estado" "arrancado esse pedaço" delas, por lhes ter "amputado" essa parte de seus corpos. Esse 
trecho revela, portanto, que a luta dessas mulheres se inscreve em uma gramática na qual o signo "mãe" é central para a mobilização política e que é em torno dessa ideia essencializada da maternidade como um atributo natural do corpo feminino que a luta acontece. Nesse sentido, o discurso das mães em luta poderia ser entendido como parte do discurso poético e estaria, portanto, em conformidade com uma modalidade semiótica na qual a linguagem poética não recalca as pulsões primárias, porém revela uma heterogeneidade irreprimível de sons e significados múltiplos não se conformando, então, às exigências da designação unívoca do simbólico (Butler, 2016a), representado pelo Estado.

No campo da linguagem, o repertório discursivo das mães revela, portanto, uma faceta do enfrentamento (do corpo) da mulher, sobretudo, (do corpo) da mãe à violência de Estado - um enfrentamento das pulsões primárias maternas que emergem no campo do semiótico e que tentam deslocar e subverter o simbólico. "Como eles ousam negar que a gente fale o nome de nossos filhos?". A fala de Dulcinéia é muito potente, tanto do ponto de vista político pelo seu caráter profundamente impactante e subversivo, quanto do ponto de vista da relação que se estabelece entre esses dois campos semânticos, "mães" $e$ "Estado", bem como entre as possíveis interpretações de Estado em jogo. Segundo Adriana Vianna e Juliana Farias (2011), no contexto carioca, o enfrentamento de mães e familiares na luta por justiça é atravessado por um marcador de gênero em que duas unidades simbólicas $e$ antagônicas se fazem presentes: de um lado, o Estado, antropomorfizado pela figura do masculino, e, de outro, as mães representadas pela figura feminina e pela maternidade que assume um protagonismo político.

As mulheres falam, assim, de uma insurgência política definida em estreitas conexões com as construções sempre em processo - de gênero. Ao falarem em nome de uma ordem doméstica que foi desfeita brutalmente pelo assassinato dos filhos, elas (e eles, no caso dos demais familiares) trazem o feminino não em seus corpos individuais, mas como marca de significação das relações 
que se romperam, bem como da violência ilegítima que as destruiu. Levam, assim, a "casa" para a cena de protesto, através do que seria o seu "centro exemplar" simbólico: a própria maternidade (Vianna; Farias, 2011:93).

As autoras oferecem as condições para compreender o modo como gênero e Estado se fazem em ato, em uma relação performativa na qual a violência opera como zona de significação (Vianna, 2014) desempenhando "papel fundamental nas relações de co-produção entre gênero e Estado" (Vianna; Lowenkron, 2017:33). É possível observar, no contexto etnográfico em questão, que a relação entre esses dois polos, mães e Estado, é construída sob o signo da violência, cujo alcance heurístico e político (Vianna; Lowenkron, 2017) garante as condições para o duplo fazer do Estado e do gênero em um campo semântico dentro do qual tais categorias ganham significado.

A fala de Dulcinéia sugere alguns caminhos para se pensar os processos de estatização do gênero e generificação do Estado, como propõem Vianna e Lowenkron (2017). No registro discursivo de Dulcinéia, é possível perceber como se estabelece certo antagonismo entre, de um lado, "as mães" com sua prerrogativa de dar à luz, de gerar a vida, em extrema oposição a uma outra categoria semântica, "o Estado", evocado para a arena de disputa semântica e fortemente marcado pela violência daquele que causa dor, sofrimento e que coloca a vida em risco. "Por que eles querem arrancar esse pedaço de nós?" (ênfase do autor). Eles se apresenta aqui como metonímia de evocação de uma ideia de Estado, em um sugestivo processo de generificação do Estado.

Ao expor a arbitrariedade da violência daqueles que "querem arrancar esse pedaço de nós", a fala de Dulcinéia expõe, porém desfragmenta aquilo que Wendy Brown (1995) definiu como uma das modalidades do poder estatal que carrega o caráter masculino do Estado, a sua dimensão prerrogativa de proteção. Para Brown, as múltiplas dimensões de masculinidade construídas socialmente atravessam e circulam os múltiplos modos de poder presentes no domínio chamado Estado. Nesse sentido, o domínio 
masculino da vida política informa quem tem a prerrogativa de proteger e quem deve ser protegido, dentro de um campo semântico generificado que atribui a tarefa de proteger ao poder masculino. Entretanto, a fala de Dulcinéia, ao evocar "o Estado" como interlocutor discursivo, revela o revés da sua prerrogativa de proteção, ou seja, seu poder de matar, expondo, então, a face mais brutal e perversa das práticas de Estado, cujo caráter generificado é performatizado publicamente pelos seus gritos de mãe.

Sob o signo da violência, mães e Estado constituem-se de modo relacional na medida em que, à luz deste registro etnográfico, estabelecem-se marcadores que diferenciam $e$ posicionam esses dois campos semânticos, como categorias antagônicas, porém intimamente conectadas. Mais do que expor a fragilidade sobre a qual se assenta a dimensão prerrogativa do Estado de proteger, a fala de Dulcinéia mostra que, no domínio masculino da vida política, o privado se constitui como um lugar de acesso privilegiado do homem à mulher, como argumenta Brown (1995), lugar sobre o qual o Estado é capaz de produzir profundas feridas. Nesse sentido, as mães expõem a público aquilo que se constitui na violação do mais íntimo delas, do âmbito da família, promovido pela intervenção daqueles (ênfase do autor) que, ao invés de proteger, colocam a vida em risco. $\mathrm{Na}$ linha argumentativa de Brown (1995), a dimensão prerrogativa de proteger do Estado, caracterizada pelo monopólio do uso legítimo da violência, garante àqueles que circulam pelos domínios de poder do Estado a preocupação não com o bem-estar da população, mas sim com o prestígio da dominação que se torna algo mais importante do que a vida como valor supremo. Nesse sentido, no domínio masculino da vida política, é a dominação sobre a vida o código sob $\mathrm{o}$ qual opera o processo de generificação do Estado.

"Mães" e "Estado" não se constituem meras categorias antagonicamente opostas e separáveis, mas sim conectadas sob o signo da violência normalizada como parte de um pertencimento generificado ao Estado-nação, como argumenta Veena Das 
(2008b). Segundo a autora, violência e intimidade estão intrinsecamente relacionadas na medida em que a violência, vista como zona de significação nas palauras de Vianna (2014), acaba sendo parte do vínculo do sujeito ao Estado-nação. Nesse contexto de luta, a violência é parte constitutiva da relação entre mães que habitam o campo do semiótico, seguindo os rastros de Kristeva, e o Estado como aquele cuja violência incide sobre o íntimo delas. No entanto, a saída das mães às ruas - para trazer a público "a dimensão pessoal sustentada nas falas sobre o sofrimento que não finda" (Vianna, 2014:235) - embaralha as noções cristalizadas entre público e privado, justamente por evidenciar sua íntima conexão. Nesse sentido, o semiótico e a esfera do privado são tanto condições de possibilidade para a manutenção de um imaginário político moderno centralizado no Estado como o garantidor da ordem e provedor da proteção, como condições de possibilidade para, como fazem as mães ao romperem a barreira do privado, revelar a violência como um terreno político que atribui significados, lugares e papéis bem definidos aos sujeitos. Sendo o semiótico tanto condição para quanto produto do simbólico em uma relação inseparável na qual funciona dentro de práticas significantes a fim de transgredir o simbólico, como reconhece Kristeva, o papel desempenhado pelas mães nesse cenário atua no sentido, então, de subverter a estrutura do simbólico, por meio da qual as práticas violentas de Estado são performatizadas, a fim de trazer a expressão da maternidade à materialidade da linguagem.

A potência das falas de mães e familiares vítimas da violência institucional reside na forma pela qual esses atores produzem continuamente o Estado, sendo este ora evocado metonimicamente como aqueles que "querem arrancar esse pedaço de nós", como na fala de Dulcinéia, em alusão aos policiais militares que tiraram a vida de seu filho, ora como aquele "que me abandonou quando eu cresci" [...] "que torturou e matou meu filho", em que o Estado é tomado como uma entidade, como na fala de Carmen. O Estado aqui se faz pela sua onipresença, marcada de forma simultânea tanto pela falta quanto pela 
presença, ambas capazes de produzir dores insuperáveis. É preciso reconhecer, como argumentam Vianna e Lowenkron (2017:49), os "acionamentos posicionados e estratégicos que permitem simultaneamente desagregar ou condensar o que seja o Estado: ora epíteto geral e englobante, ora materialidade específica". Esse trânsito, entre uma noção abstrata e ideológica do Estado e o Estado como fenômeno que apresenta concretude no cotidiano, seria talvez uma das poucas formas possíveis que tais atores vitimados pela violência de Estado teriam de garantir as condições para reivindicar justiça e, assim, um sentido para suas vidas. ${ }^{7}$

Os encontros entre mães e familiares são atravessados continuamente pelo processo de generificação do Estado $e$ estatização do gênero, como argumentam Vianna e Lowenkron (2017), no qual as mães são sujeitos politicamente tecidos nessa trama simultaneamente à masculinização do Estado. Entretanto:

A masculinização do Estado nesse caso, longe de ser tomada como atributo a priori, deve ser entendida como ação discursiva só compreensível pela simultânea produção de uma figura feminina que lhe faz frente e cujo sentido último é encontrado na relacionalidade profunda da maternidade (Vianna; Lowenkron, 2017:26).

A maternidade, em sua visão mais essencializada, é o elemento por trás do qual toda uma rede de mulheres se mobiliza

7 Adriana Vianna e Laura Lowenkron partem do diálogo com as reflexões de Philip Abrams (1988) sobre as formulações teóricas acerca do estatuto ontológico $e$ ideológico do Estado. Para as autoras, o trânsito discursivo entre uma noção mais abstrata e ideológica do Estado e o Estado como uma realidade concreta na vida de tais atores vítimas da violência estaria associado à relação entre o que Abrams chamou de "Estado-sistema", que compõe as práticas burocráticas e institucionais, e "Estado-ideia", como uma estrutura fundamental e oculta. Para Abrams, é sobre essa potente relação que repousa o caráter ilusório de que há um ente oculto, um ente chamado Estado a ser revelado. No contexto etnográfico no qual me insiro, é justamente sobre esse movimento entre uma noção ora indefinida e incerta sobre o que é o Estado, ora mais qualificável em termos das práticas cotidianas que participam dos processos de produção de Estado, que a luta de mães e familiares é acionada. 
na reivindicação por justiça. Entretanto, se em um primeiro momento parece que as mães reforçam ainda mais uma essência do que é ser mãe - agora sendo também aquela que deve lutar pelo filho que se foi -, é justamente trazendo à frente do movimento a ideia essencializada de maternidade que elas ressignificam esse papel. Se, historicamente, coube à mãe cuidar dos filhos e manter-se no domínio da casa, o que essas mulheres fazem é mostrar que ser mãe pode ser também sair de casa e gritar publicamente a vida do filho que "o Estado" tirou.

Ao contrário de uma leitura cristã na qual leite e lágrimas são tudo o que resume a maternidade, sob o constructo da mater dolorosa, para essas mães, ocupar espaços públicos gritando a morte do filho também acaba sendo um atributo que lhes compete. Às mães não lhes resta somente chorar, mas elas podem também lutar. Paradoxalmente, a essencialização de maternidade pela qual o movimento de mães atravessa, ao operarem no terreno semântico da mãe que sofre e chora, acaba por lhes fornecer também as condições para que ressignifiquem a própria ideia de maternidade, uma vez que a luta tanto aproxima e reforça a ideia de mater dolorosa como a afasta e transcende. Se a ideia de mater dolorosa é aquela cujos signos se estruturam em um terreno pré-discursivo, no campo da não linguagem em que as lágrimas resumem uma existência atrelada à dor e ao sofrimento, como afirma Kristeva (1985), as mães do contexto em questão não se restringem somente a chorar silenciosamente a morte de seus filhos, mas rompem com esse silêncio.

A gente só pede justiça, a gente só pede pelo fim dessa impunidade, porque enquanto a impunidade imperar nesse Brasil, todos os dias, jovens pobres, negros e periféricos continuarão sendo assassinados. Todos os dias, mães estarão sendo impedidas de exercer sua maternidade. Todos os dias, as mães pretas, as mulheres pobres das favelas e periferias estarão sendo impedidas de conviver com seus filhos [...] a gente não aceita mais ser mutilada todos os dias! (fala de Selma, mãe de Tiago, em ato em frente ao Ministério Público do Rio de Janeiro, em dezembro de 2017). 
A fala de Selma apresenta a maternidade como um terreno sobre o qual as práticas de Estado, por meio de seus dispositivos de violência, mantêm-se e se reproduzem. Este registro aponta para umas das formas pelas quais se dá o "processo de formação de Estado" que, como argumenta Antônio Carlos de Souza Lima (2012:561), resulta "em processos de objetificação e de subjetificação que operam construindo e desconstruindo realidades no plano da vida diária". No contexto narrativo em questão, é possível compreender a maternidade, signo político dessa luta, como um terreno sobre o qual esse "fazer Estado" acontece, processo constante e que se sustenta sobre aquelas que, como afirma Selma, são "impedidas de exercer sua maternidade" e "mutiladas todos os dias". A maternidade se revela, aqui, como nódulo da complexa organização política do Estado e, no entanto, sob o constructo ressignificado de uma maternidade que (en)luta, é capaz de tensionar os enquadramentos estatizantes do gênero dentro dos quais ela é constantemente apreendida pelas instituições. $^{8}$

Uma leitura mais cuidadosa sobre a questão da maternidade nesse contexto de luta deve levar em conta as condições sob as quais essas mães vivem, ou seja, as interseções entre marcadores sociais da diferença, como raça, classe e gênero, que atravessam as relações em que estão inseridas. A disputa em torno da maternidade como um conceito só faz sentido, nesse contexto etnográfico, se considerada à luz da interseccionalidade das relações sociais presentes nas trajetórias de vidas dessas mulheres. ${ }^{9}$ Há outros elementos em jogo, como raça e classe, que

8 Esse registro etnográfico foi feito durante a realização de um ato em frente ao Ministério Público do Estado do Rio de Janeiro, em dezembro de 2017, organizado pela Rede de Comunidades e Movimentos contra a violência, no contexto de lançamento da campanha "Caveirão Não! - Favelas pela Vida e contra as Operações", como forma de pressionar o Ministério Público no aceleramento dos mecanismos de investigação dos crimes cometidos pelas operações militares nas favelas cariocas.

9 Ainda que o debate sobre as interseções entre gênero, raça e classe não seja o foco deste artigo, parto do referencial teórico de Avtar Brah (2006) para quem 
compõem o cenário de luta das mães cuja complexidade extrapola um diagnóstico que se resume a ver a maternidade como opressora ou libertadora, como vemos no debate entre Butler e Kristeva. A maternidade, nesse contexto em discussão, traz à tona um entrecruzamento entre as relações sociais que deve ser levado em conta.

Patricia Hill Collins, em suas análises sobre as famílias negras afro-americanas nas quais a figura da mulher é central, é assertiva ao defender que a maternidade acaba sendo ressignificada sob certas condições de violência extrema. Em seu livro Black Feminist Thought (2000), Hill Collins afirma que a tradição afro-americana traz consigo uma perspectiva tanto de família quanto de comunidade na qual as mulheres ganham papel crucial no cuidado das crianças, mesmo aquelas que não são suas. Segundo a autora, é comum em famílias de comunidades afroamericanas os arranjos e revezamentos entre mulheres no cuidado de filhos que não são seus. Em um contexto em que as mulheres de famílias negras e pobres trabalham como domésticas e cuidam de crianças de famílias de classe média, os seus filhos ficam sob a responsabilidade do cuidado de outras mulheres da comunidade ou até mesmo de irmãs, avós e tias. Esses arranjos entre mães de sangue e outras mães na política do cuidado das crianças negras $e$ de comunidades pobres revelam uma estratégia para lidar com, $e$ resistir às, opressões de classe, raça e gênero que se sobrepõem a essas famílias.

No contexto do Rio de Janeiro, o engajamento dessas mães na luta por justiça é atravessado por um cenário no qual muitas têm que trabalhar para sustentar a família, o que dificulta a sua

não é o "gênero", mas sim a "diferença" que se constitui em uma categoria analítica, daí minha escolha pelo uso lexical de "marcadores sociais da diferença" como gênero, raça e classe que se entrecruzam, ou dos "entrecruzamentos das relações sociais" em jogo, como faz Roberto Efrem Filho (2017), ou ainda da "articulação entre as múltiplas diferenças" como faz Adriana Piscitelli (2008) em suas reflexões sobre o debate conceitual acerca dessas categorias como "categorias de articulação". Ver também o mapeamento analítico dessa discussão feito por Laura Moutinho (2014). 
participação ativa em atos, na busca de informações, pistas, autoridades, no acionamento de instituições etc. ${ }^{10}$ As condições socioeconômicas que marcam essas famílias acabam ressignificando a ideia de maternidade, na medida em que o apoio de outras mulheres e familiares é crucial para o enfrentamento dessas dificuldades pelas mães.

Diante das condições de vida de muitas famílias negras em favelas cariocas, a maternidade ganha uma complexidade marcada também por questões de classe e raça, uma vez que, diante do "evento traumático" (Das, 1996) da perda de um filho, muitas mães, além de trabalharem fora para sustentar a familia, acabam assumindo para si a responsabilidade da luta pelos filhos mortos ou desaparecidos. Nesses contextos, a união com outras mães na luta é atravessada por uma série de enfrentamentos às articulações das múltiplas diferenças de gênero, classe e raça.

No debate entre as feministas, há quem diga, como Julia Wells (apud Hill Collins, 2000:193), que as mulheres desses movimentos políticos em defesa de seu papel como mãe "não estão lutando por seus próprios direitos pessoais como mulheres, mas por seus direitos de custódia como mães" e que, portanto, essa política maternal seria limitada em seu escopo de atuação $e$ politicamente imatura. Entretanto, para Hill Collins (2000), essa distinção que Wells faz acaba por estabelecer uma hierarquia de feminismos, atribuindo a essas mulheres um status secundário $e$, sobretudo, falhando em reconhecer a maternidade como um símbolo de poder.

Criar suas crianças negras em ambientes racistas promove novas visões de maternidade para muitas dessas mulheres.

\footnotetext{
${ }^{10}$ Paula Lacerda (2012) discute sobre os custos do engajamento de mães e familiares na militância que, no contexto de classe em que estão inseridos, acabam se impondo como dificuldades à mobilização. Entretanto, para a autora, esses custos passam a ser vistos como irrelevantes diante da inevitabilidade do engajamento. Para as mães que decidem entrar na luta com as demais em busca de justiça, a mobilização é vivida não como uma escolha, mas como a única opção possível.
} 
Esse é um entendimento totalmente diferente de ativismo político e empoderamento do que lutar em causa própria. Rotular esse tipo de individualismo socialmente responsável como "politicamente imaturo" parece muito equivocado (Hill Collins, 2000:194).

Essa perspectiva revela um outro entendimento do que é maternidade e do que é viver em comunidade, especialmente em comunidades que estão sob violência extrema de Estado que atinge não somente uma família ou um indivíduo específico, mas toda uma população que compartilha os efeitos perversos ocasionados pelas múltiplas relações em jogo. A disputa em torno do conceito de maternidade através das lentes de um feminismo que não leva em conta os contextos de guerra em que está inserida determinada população - e que tampouco se atenta às complexidades da interseccionalidade de marcadores como raça, classe e gênero - deve ter seus horizontes minimamente problematizados.

Ao fim e ao cabo, o que podemos perceber é que há uma série de problematizações em torno da ideia de maternidade que são atravessadas por questões de gênero inesgotáveis. Entretanto, a despeito de todas as problemáticas envolvidas, ao tomar a maternidade como um conceito único e romantizado, no contexto da luta dessas mães é esse conceito de maternidade - catalisado pelo amor de mãe - que define um espaço e um poder à mulher. O lugar materno não é, nesse sentido, desprovido de poder (Freitas, 2002), pelo contrário, "a maternidade permanece como um símbolo de esperança para muitas das mulheres negras $e$ pobres" (Hill Collins, 2000:198) e é justamente o lugar materno que lhes garante a dimensão política de sua luta.

O movimento realizado pelas mães ao saírem de suas casas e se fazerem sujeitos políticos visíveis para a sociedade é o de transformar a imagem de mater dolorosa ou mãe sofredora na imagem de "mãe que luta" (que não exclui a primeira), mãe corajosa que enfrenta a polícia (Freitas, 2002) e não tem medo "do Estado que mata seus filhos". Transformar a dor que sentem em 
mobilização política é algo que as preenche como sujeitos e as faz renascerem a partir dessa dor, desse amor de mãe (Freitas, 2002). Nesse sentido, poderíamos pensar que a mobilização das mães em torno de uma ideia romantizada de maternidade se constitui em uma estratégia para agenciar processos que responsabilizem os algozes "desse Estado que mata". É esse "ser mãe" que as torna mulheres destemidas, invocando "o Estado" para esse campo de batalha.

Nesse contexto de luta, o corpo adquire tal importância, pois é nele que está inscrito um passado ainda muito vivo no presente das mães, qual seja, o passado com a memória de seus filhos assassinados. Segundo Paula Lacerda (2014), o alcance da violência de Estado extrapola os limites do corpo do filho, manifestando-se concretamente na vida das mães. Segundo a autora, embora a violência institucional se apresente de forma direta sobre o corpo do filho, o corpo materno traz também as marcas da violência de Estado, pois esta se manifesta concretamente na vida e nos corpos das mães na forma da dor. As doenças respiratórias, a depressão, a falta de vontade de viver são sintomas da tortura física infligida nos filhos e sentidos nos corpos das mães e familiares (Lacerda, 2014). ${ }^{11}$ Nesse sentido, o trabalho da autora revela a importância da dimensão do corpo materno como a própria denúncia das vidas que foram violadas pelas práticas de instituições de Estado, justamente por trazer a público

\footnotetext{
${ }^{11}$ Em julho de 2016, faleceu Joselita, mãe de Roberto, um dos meninos assassinados no caso da chacina de Costa Barros, de 2015. Segundo os médicos, a mãe chegou ao hospital com um quadro grave de pneumonia e anemia. Segundo os familiares, Joselita "morreu de tristeza", pois não conseguia comer direito depois do assassinato do filho. São recorrentes os casos de mães que adoecem após o "evento traumático" de perda do filho, nesse contexto. O caso de falecimento de Joselita saiu no Jornal $O$ Globo intitulado como "Após mãe 'morrer de tristeza', médicos cobram apoio para 'sobreviventes'”. Esse caso é um triste exemplo do impacto da violência de Estado nos corpos das mães, vítimas indiretas dessa guerra [http://oglobo.globo.com/sociedade/saude/apos-maemorrer-de-tristeza-medicos-cobram-apoio-para-sobreviventes-19690199 - acesso em: 24 jan. 2017].
} 
a memória de um passado que está registrado sobre um corpo que se expressa pela linguagem do sofrimento e da dor.

O tempo é, então, consubstanciado, materializado no corpo da mãe. A maternidade, nesse contexto, é apresentada como uma forma de experiência corpórea-temporal na qual passado, presente e futuro estão inextricavelmente ligados à matéria, ao corpo. Um dos argumentos de Söderbäck (2010) sobre as reflexões de Kristeva é o de que, para esta, o corpo materno representaria a continuidade entre o tempo e a matéria no sentido de que tanto o tempo é corporificado quanto os corpos são temporais. Essa perspectiva seria uma forma de rearticular espaço-temporalidade de modo a desafiar a tradição milenar que separa o tempo e o espaço, atribuindo o primeiro à mente consciente e o segundo à corporificação.

Luce Irigaray, em An ethics of sexual difference (1993), explica que a problemática do espaço-tempo, em todas as genealogias dos deuses, gira em torno da ideia de que, primeiramente, houve a criação do espaço. Deus criou o espaço. E o tempo estaria a serviço do espaço, sendo Deus a personificação do próprio tempo. Irigaray segue afirmando que, na Filosofia, o tempo se torna a interioridade do sujeito e o espaço, sua exterioridade. O sujeito seria, portanto, o mestre do tempo, que ordena o mundo e Deus teria efetivado a passagem entre o tempo e o espaço. A autora afirma que nossa percepção de espaço-tempo estaria estruturada em torno da ideia de que o feminino é experienciado como o espaço e o masculino como o tempo. Nessa gramática, à figura do feminino-materno seria atribuído o papel de um envelope, um container, um lugar para o homem, o qual seria o ponto de partida para a delimitação das coisas, do espaço. Segundo Söderbäck (2010), o entendimento de Kristeva sobre o corpo materno como uma temporalização vai na direção oposta, qual seja, a de (re)pensar o tempo e o espaço como intrinsecamente inseparáveis e, portanto, inaugurando uma nova noção de tempo tridimensional que se resume na experiência e no corpo maternos. 
A potencialidade do pensamento de Kristeva acerca da maternidade, segundo Söderbäck (2010), está justamente em retornar ao corpo materno não para congelar a mulher em uma estrutura de significação linguística e sob o domínio de uma cultura de reprodução compulsória, como critica Butler (2016a), mas para liberá-la de um papel pré-definido de maternidade como a única forma de subjetividade disponível a ela. O esforço de Kristeva ao retornar ao corpo materno seria, então, o de prover a mulher de um passado e um futuro, sendo o futuro o que está em jogo, na medida em que o futuro significa a possibilidade de uma mudança temporal. O corpo materno

àquele ao qual nós retornamos é temporal, móvel, deslocável, renovável. O retorno não é nem nostálgico nem pretende preservar alguma noção essencial de maternidade; ele torna possível novos começos, permitindo um futuro gestado de mudança e transformação (Söderbäck, 2010:3).

Nesse sentido, Kristeva parece fazer um retorno ao materno para manter aberto um futuro de possibilidades que possui no corpo da mãe uma expressão temporal rítmica. Os discursos das mães do Rio de Janeiro acabam sendo uma expressão desse esforço teórico. No contexto da luta das mães, a potencialidade de retornar ao corpo materno caminha na direção de entender o corpo como temporal em si mesmo, carregando nele um passado cujas marcas se materializam em um presente de dor e cujo futuro lhe é negado. Nesse sentido, o corpo da mãe se constitui na própria denúncia da violência de Estado, pois traz em si mesmo a destruição de um passado que é carregado em um presente de dor $e$ um futuro que lhes é constantemente negado. A violência de Estado lhes nega a possibilidade $e$ a potencialidade de serem mães.

Em consonância com o esforço teórico de Julia Kristeva, diferentemente da recusa de ser mãe, o que é potente nessa luta é a tentativa de encontrar e/ou garantir um outro discurso para a maternidade, um discurso no qual as mulheres expõem a violência à qual estão submetidas enquanto mães, não somente no sentido 
de terem perdido os seus filhos, mas, sobretudo, no sentido de revelar o impacto da violência de Estado no apagamento da experiência materna do campo da linguagem. Os discursos das mães se constituem, portanto, em uma ruptura com esse silenciamento e numa tentativa de denúncia dessa estrutura simbólica que reduz a mulher a um campo de ocultamento.

\title{
Um corpo que não aguenta mais
}

As perguntas que sempre me faço ao olhar o movimento de mães são: de onde é que essas mulheres tiram tanta força para lutar? Onde reside a força das mães? Como pode um corpo suportar tanto dor?

\begin{abstract}
[...] eu quase não queria vir aqui hoje, mas eu falei "não, eu tenho que ir [...], eu tenho que passar por cima desse sentimento", porque é difícil, mas não é impossível, quando uma mãe ela tira de dentro do seu íntimo forças pra poder lutar; tem dias que eu tenho vontade de ficar na minha casa, com a esperança que eu vou ver o Pedro entrar por aquela porta $e$ eu sei que não vai $e$ isso me dói cada dia mais. Eu estou fazendo uma obra na minha casa que é pra eu não ter lembrança mais, porque eu não aguento nem ficar dentro da minha casa [chorando]. Eu estou tentando mudar meus sonhos, meus projetos, pra poder diminuir essa dor, essa saudade que eu sinto do meu filho (fala da mãe Carmen, em ato na favela de Manguinhos em 2015, ênfase do autor).
\end{abstract}

Parece-me uma tarefa difícil, diante da dor alheia, não se fazer esses tipos de questionamentos, afinal, como levar adiante uma vida marcada pela dor de uma perda inaceitável?

Para o filósofo David Lapoujade (2002), o sofrimento não é um estado particular do corpo, mas sim a condição primeira do corpo e sofrer se traduz em estar exposto ao fora, ao que lhe pode afetar de alguma maneira. Sofrer é estar exposto aos encontros com outros corpos, com a luz. E o corpo é aquele que já não aguenta mais essa exposição. A fala de Carmen sugere que seu corpo é um corpo que suporta o insuportável, é um corpo que 
vive o invivível. É como se, mesmo ao chegar ao limite do insuportável, esse corpo tirasse "de dentro do seu íntimo forças para poder lutar", como afirma.

Viver é uma constante luta para essas mulheres, uma luta ao que está fora dos limites do próprio corpo e que, no entanto, afeta-lhes em seu mais íntimo. Viver, para essas mulheres, é ter que se deparar com a violência de Estado que atinge os seus filhos $e$ os seus próprios corpos $e$, no entanto, ter que sustentar um corpo que vive a precariedade maximizada pelas práticas violentas de Estado. Para Butler (2016b), a condição de precariedade inerente ao próprio corpo marca a sua vulnerabilidade em relação ao mundo exterior. Sua sobrevivência é necessariamente dependente de uma (infra)estrutura que lhe forneça as condições para que siga (sobre)vivendo. No contexto de luta das mães, ao que me parece, viver é lutar contra tudo aquilo que está fora e, sobretudo, contra a própria capacidade de suportar o que já não parece ser mais suportável. O Estado brasileiro, ao qual o movimento de mães se dirige na reivindicação de justiça, é justamente "aquele que viola seus direitos", expõe suas vidas ainda mais à morte e as empurra para uma condição ainda mais precária. Butler (2016b:52) afirma que "viver é sempre viver uma vida que é vulnerável desde o início e que pode ser colocada em risco ou eliminada de uma hora para outra a partir do exterior $e$ por motivos que nem sempre estão sob nosso controle".

Pra gente é difícil, sempre que eu estou falando, que eu encontro com outras mães, eu sempre falo, esse Estado terrorista, genocida, assassino, tirou meu filho de mim, eu perdi meu filho. Mas infelizmente a minha filha perdeu o irmão e perdeu um pouco da mãe dela. Porque a gente não consegue entender, a gente não consegue viver, não é que a gente não queira, a gente quer viver. [...] Mas a gente não consegue, não é porque a gente quer ficar triste o tempo todo, é uma coisa mais forte que a gente. E eu costumo dizer que a gente não vive, a gente sobrevive [...] (Selma, mãe de Tiago, em ato na favela de Manguinhos em 2015, ênfase do autor). 
A fala de Selma revela a condição de precariedade maximizada à qual sua vida foi submetida após o "evento traumático" da perda de seu filho, Tiago. A dor causada pela perda, carregada em um cotidiano de sofrimento no qual ela tenta lidar com a falta de vontade de viver, sugere que, ainda que todos vivamos em uma condição de precariedade, esta não é distribuída de forma igual a todos. Para alguns, a vulnerabilidade do corpo é maximizada pela violência desproporcional de Estado a que estão submetidos. Para estes, certamente, a precariedade se torna mais latente, seguindo o diagnóstico de Butler (2016b).

O poder que incide sobre as mães já não é um poder que se exerce desde fora, um poder transcendente, apenas repressivo, mas sim um poder imanente, um poder produtivo que se exerce sobre a vida (Foucault, 1999). Ao contrário de seus filhos, sobre cujos corpos foi exercido um poder de matar, de barrar a vida, como um poder soberano que faz morrer, sobre as mães há um poder que as faz viverem não uma vida, mas uma sobrevida. Segundo Selma, as mães não vivem, elas sobrevivem. Para Pelbart (2007:59), "quando a vida é reduzida" a essa condição de sobrevida, "aparece a perversão de um poder que não elimina o corpo, mas o mantém em uma zona intermediária entre a vida e a morte, entre o humano e o inumano. É o sobrevivente".

A gente não aguenta mais! A gente vai continuar lutando até essas instituições, até esse Brasil tomar vergonha nessa cara! O que nós estamos fazendo aqui hoje é luta! A gente está lutando pela nossa sobrevivência. E a gente está aqui pra dizer, que enquanto a gente tiver força, vamos continuar sendo a voz dos nossos filhos, daqueles que nos foram arrancados e daqueles que continuam nas favelas $e$ nas periferias. Nossos filhos têm mães! [...] Enquanto a gente viver, vamos lutar por eles! (fala de Selma, mãe de Tiago, em ato em frente ao Ministério Público do Rio de Janeiro, em dezembro de 2017). 
Como se pode observar nessa fala de Selma, é justamente pela exposição pública da condição maximizada de precariedade à qual essas mulheres foram submetidas que seus corpos são constantemente performatizados como sujeitos políticos frente à arbitrariedade da violência de Estado. A exposição da condição maximizada de precariedade, acionada nas inúmeras falas, compõe um repertório estratégico que torna a própria precariedade, nesse contexto de luta, uma potência, garantindo a essas mulheres as condições de possibilidade para tentar superar o sofrimento que se converte, aqui, em formas de agenciamento político. A reiterada exposição pública da dor se traduz em uma das chaves para compreender o modo como se dá o processo de subjetivação dessas mães (de) vítimas da violência de Estado.

A luta das mães se centra tanto em torno da morte, pois é em decorrência do assassinato de seus filhos que a luta política acontece, quanto da vida, pois ao fim e ao cabo, essa luta é uma disputa pela vida, para que seja digna de ser vivida. É justamente nesse limiar entre a vida e a morte, no ponto em que o poder incide com maior força sobre a vida, que a resistência surge (Foucault, 1999). E é precisamente quando a vida é reduzida ao mero ser, uma vida enraivecida, indignada, resistente, que ela atinge seu maior valor (Butler, 2015).

É interessante pensar nas formas de resistência que mobilizam a vulnerabilidade para fazer valer a existência, reivindicando o direito ao espaço público, à igualdade e se opondo a uma polícia violenta, à (in)segurança $e$ às ações militares. No contexto de luta dessas mães, a reunião no espaço público é uma forma de resistência política que expressa e demonstra, através do próprio corpo, a precariedade a que estão submetidas. Esse corpo que se coloca nos espaços públicos é um corpo precário que denuncia um processo no qual a vulnerabilidade em alguns se torna mais marcada que em outros.

A potência do movimento das mães nos espaços públicos diz respeito ao direito de aparecimento, trazendo seus corpos como a própria denúncia da violência de Estado. Sua reivindicação por justiça é uma forma de dizer que elas ainda 
estão ali persistindo (Butler, 2015), mesmo em uma condição de precariedade levada ao extremo. Sair de suas casas, das favelas $e$ protestar em outros espaços da cidade é uma forma de revelar uma verdade que permeia a política de pacificação da cidade do Rio de Janeiro, a de que há uma distribuição demograficamente desigual da precariedade e que, nesse sentido, ela recai com muito mais força nos espaços de favela. Ocupar o espaço público é, então, uma forma de reivindicar que todas as vidas devem ser tratadas com igualdade e devem ser igualmente vivíveis.

Outra potencialidade do movimento de mães está no fato de que elas estão nas ruas pela memória de seus filhos, para lembrar das vidas que foram perdidas. Deixar de falar em nome de seus filhos seria o mesmo que aceitar que aquelas eram vidas sem importância e sem valor. "Apenas em condições nas quais a perda tem importância o valor da vida aparece efetivamente" (Butler, 2016b:32). Dessa maneira, estar nas ruas é um modo de dizer que aquelas vidas importam e que, portanto, se forem perdidas devem ser enlutadas. Para Butler (2016b), uma vida só tem seu valor quando sua perda é passível de luto.

Um dos efeitos do "estado de guerra" vivido na cidade do Rio de Janeiro é dividir a população entre aquelas pessoas que merecem viver e aquelas que não merecem. Consequentemente a essa clivagem está o fato de que algumas vidas, se perdidas, não são passíveis de luto, não são passíveis de ser enlutadas, justamente por nem serem consideradas vidas. De acordo com Butler,

podemos ver a divisão do mundo em vidas passíveis ou não passíveis de luto da perspectiva daqueles que fazem a guerra com o propósito de defender as vidas de certas comunidades e para defendê-las das vidas de outras pessoas, mesmo que isso signifique eliminar estas últimas (Butler, 2016b:64). 
Vou me colocar aqui como irmã de vítima de violência de Estado. Esse momento aqui da manifestação é muito profundo pra mim, porque foi buscando respostas do porque meu irmão morreu que eu sou a pessoa que eu sou hoje. Lógico, com todas as feridas, com toda a revolta, mas uma revolta que fortalece. Cada lágrima que eu derramo é a certeza de que eu não aceito [gritando e chorando] e não me interessa, não vem dizer pra mim que um merece morrer $e o$ outro não merece! Aqui a gente não tem pena de morte $e$ isso tem que ficar bem claro pra não dizer que um tem que morrer e o outro não! Meu irmão não mereceu morrer! (fala de Paula, irmã de jovem assassinado pela polícia, em semana de homenagem às Mães de Acari, na $\mathrm{OAB} / \mathrm{RJ}$, em 2015, ênfase do autor).

Como podemos perceber nessa fala, o que o movimento de mães e familiares de vítimas da violência de Estado faz é evidenciar a "distribuição desigual do luto público" (Butler, 2016b:65), como uma forma de denunciar a injustiça que recai sobre suas vidas. Essa é uma questão política da maior importância. Para Butler (2015), a precariedade acaba tornando-se um lugar de aliança, é o elo que une as populações mais expostas à violência de Estado não somente na reivindicação de direitos, como também no questionamento do próprio caráter do espaço público no sentido de que o que se constitui como público está também em disputa.

A dimensão política do movimento de mães reside também, portanto, no cruzamento das fronteiras entre o público e o privado, transgredindo as fronteiras do lugar da política. Esses corpos precários que vemos nas ruas são corpos que, em sua pluralidade, reivindicam o público, procuram e produzem $\mathrm{o}$ público.

O "verdadeiro" espaço reside então "entre as pessoas", o que significa que na medida em que a ação toma lugar em algum local, ela também estabelece um espaço que pertence propriamente à aliança em si. [...] Espaço e lugar são criados através da ação plural (Butler, 2015:73). 
A ação coletiva do movimento de mães desloca o político para a sua própria ação que ganha outros significados na medida em que elas são o político, por excelência.

Pensar o corpo cuja condição precária é reforçada pela vulnerabilidade à distribuição desigual da precariedade não significa pensar esse corpo como um corpo fragilizado, impotente, como um corpo destituído de qualquer possibilidade de ação. Contrariamente, afirmar que um corpo é precário não é uma fraqueza da potência, mas sim a potência de resistir do corpo (Pelbart, 2007) e as mães trazem ao espaço público essa potência da resistência em seus próprios corpos.

De volta à minha pergunta inicial, "onde reside a força das mães?", a resposta me parece ser exatamente esta: sua força reside justamente na aliança da ação coletiva em expor a precariedade a que estão expostas em relação ao Estado. Expor publicamente essa precariedade me parece ser uma condição para que elas questionem os perigos a que estão expostas. Nesse sentido, tanto a resistência quanto a vulnerabilidade operam juntas em uma mesma chave estratégica, a fim de denunciar a violência de Estado que recai sobre a população negra, pobre $e$ favelada.

\section{Algumas considerações finais}

Neste artigo, apresentei uma reflexão acerca dos limites $e$ potencialidades da maternidade como um símbolo em constante disputa. A partir disso, pensar a maternidade através de uma chave interpretativa na qual ela é compreendida apenas como uma construção cultural compulsória sobre a mulher e, dessa forma, seguida de uma atitude política de recusá-la é insuficiente para analisar as complexidades que giram em torno do papel da maternidade em comunidades negras. $\mathrm{O}$ fato de que a maternidade, historicamente, foi tida como uma obrigação compulsória a muitas mulheres não deve impedir ou desqualificar a luta política de algumas mulheres por reivindicarem o direito de serem mães e continuarem a ter seus filhos vivos. 
No contexto do movimento de mães do Rio de Janeiro, a noção essencializada de maternidade lhes permite denunciar o excesso de poder do Estado que, ao matar o filho, realiza um corte violento de uma ligação simbólica entre dois corpos, ligação que nunca se desfaz para essas mães. Ao infligir violência contra o corpo do filho, o corpo da mãe também sente a dor e, nesse sentido, as mães se tornam segundas vítimas dessa "guerra". A própria mobilização da noção essencialista do que é ser mãe é o que lhes garante as condições de possibilidade para ressignificar a maternidade e, através dela, garantir um peso político para sua luta.

A condição de vulnerabilidade não significa, entretanto, que o corpo deve ser reduzido à condição de violável. O corpo das mães, por mais precário que seja, continua vivo, respira, indignase e apresenta uma capacidade de resposta que se traduz no processo de luta e de luto públicos. A potência desse movimento se revela justamente no esgarçamento de um corpo que se encontra no ápice da sua condição de precariedade. A linguagem que o corpo aciona se traduz em um direito de estar ali, de aparecer em público e de exercer um direito que é negado a todo momento. É um corpo que traz inscrito em si mesmo um passado destruído pela força militar, um presente violado pela impunidade do Estado e um futuro a ser marcado pela esperança de um dia poder viver mais dignamente. Esse corpo que (en)luta escreve uma história de resistência a partir desse corpo que fala, que grita. A luta das mães, nesse sentido, faz parte dessa narrativa de guerra apresentando, no entanto, um outro lado, o lado dos que ficaram para lutar e resistir.

\section{Referências bibliográficas}

ABRAMS, Philip. Notes on the Difficulty of Studying the State. Journal of Historical Sociology, vol.1, n¹, 1988, 1977, pp.58-89.

ARAúJO, Fábio Alves. Do luto à luta: a experiência das Mães de Acari. Dissertação (Mestrado em Sociologia e Antropologia), Instituto de 
Filosofia e Ciências Sociais, Universidade Federal do Rio de Janeiro (UFRJ), 2007.

BORNEMAN, John. Reconciliation after ethnic cleansing: listening, retribution, affiliation. Public Culture, 14 (2), 2002, pp.281-304.

BRAH, Avtar. Diferença, diversidade, diferenciação. cadernos pagu (26) Campinas-SP, Núcleo de Estudos de Gênero-Pagu, 2006, pp.329376.

BROWN, Wendy. States of injury. Princeton, N.J., Princeton University Press, 1995.

ButLER, J. Notes toward a performative theory of assembly. Cambridge, Mass., Harvard University Press, 2015.

. Problemas de gênero: feminismo e subversão da identidade. $11^{a}$ ed. Rio de Janeiro, Civilização Brasileira, 2016a.

- Quadros de guerra: quando a vida é passível de luto? $2^{\mathrm{a}}$ ed. Rio de Janeiro, Civilização Brasileira, 2016b.

CERQUEIRA, Daniel et alii. Atlas da violência 2017. Rio de Janeiro, Fórum Brasileiro de Segurança Pública/IPEA, 2017 [http://ipea.gov.br/portal/images/170602_atlas_da_violencia_2017.pdf - acesso em: 02 fev. 2017].

DAS, Veena. Critical events: an anthropological perspective on contemporary India. Delhi, Oxford University Press, 1996.

. La antropologia del dolor. In.: ORTEGA, Francisco (ed.) Veena Das: sujetos de dolor, agentes de dignidad. Bogotá, Universidad Nacional de Colombia, Facultad de Ciencias Humanas; Pontificia Universidad Javeriana, Instituto Pensar, 2008a, pp.409-436.

Violence, Gender, and Subjectivity. Annual Review of Anthropology 37, 2008b, pp.283-99.

EFREM FILHO, Roberto. Os Meninos de Rosa: sobre vítimas e algozes, crime e violência. cadernos pagu (51), Campinas-SP, Núcleo de Estudos de Gênero-Pagu/Unicamp, 2017 [http://www.scielo.br/scielo.php?script $=$ sci_arttext\&pid=S010483332017000300307\&lng=en\&nrm =iso].

FouCAUlT, M. Em defesa da sociedade: curso no Collège de France (1975-1976). São Paulo, Martins Fontes, 1999. 
FreITAS, Rita de Cássia Santos. Famílias e Violência: Reflexões Sobre as Mães de Acari. Psicologia USP, vol.13, n² 2, 2002, pp.69-103.

Hill Collins, P. Black feminist thought. New York, Routledge, 2000.

IRIGARAY, L. An ethics of sexual difference. New York, Cornell University Press, 1993.

JiMENO, Mirian. Emoções e Política: a vítima e a construção de comunidades emocionais. Mana - Estudos de Antropologia Social, 16 (1), 2010, pp.99-121.

JustiçA GloBAl. Justiça Global lança o site "Onde a Polícia Mata" Homicídios cometido pela PMRJ [http://global.org.br/programas/justica-global-lanca-o-site-onde-apolicia-matahomicidios-cometidos-pela-policia-militar-do-rio-dejaneiro/ - acesso em: 24 jan. 2016\}.

KrISTEVA, J. Revolution in Poetic Language. New York, Columbia University Press, 1984. . Stabat Mater. Poetics Today, vol. 6, nº 1/2, 1985, pp.133.

LACERDA, Paula Mendes. O "caso dos meninos emasculados de Altamira": polícia, justi a e movimento social. Tese (Doutorado em Antropologia), PPGAS/Museu Nacional, Universidade Federal do Rio de Janeiro (UFRJ), 2012.

. O sofrer, o narrar, o agir: dimensões da mobilização social de familiares de vítimas. Horizontes Antropológicos, 20(42), 2014, pp.49-75.

LAPOUJADE, D. Nietzche e Deleuze: que pode o corpo. Rio de Janeiro, Relume Dumará; Fortaleza, Secretaria da Cultura e Desporto, 2002, pp.81-90.

LEITE, Márcia Pereira. Da "metáfora da guerra" ao projeto de "pacificação": favelas e políticas de segurança pública no Rio de Janeiro. Revista Brasileira de Segurança Pública, vol. 6, n 2, ago/set 2012, pp.374-389.

MARCUS, George. Ethnography in/of the World System: The Emergence of Multi-Sited Ethnography. Annual Review of Anthropology, vol. 24, 1995, pp.95-117.

PelBART, P. Biopolítica. Sala Preta, vol. 7, 2007, pp.57. 
MouTiNHO, Laura. Diferenças e desigualdades negociadas: raça, sexualidade e gênero em produções acadêmicas recentes. cadernos pagu (42), Campinas-SP, Núcleo de Estudos de Gênero-Pagu, 2014, pp.201-248.

PISCITELLI, Adriana. Interseccionalidades, categorias de articulação $e$ experiências de migrantes brasileiras. Sociedade e Cultura, vol. 11, $\mathrm{n}^{\circ}$ 2, 2008, pp.263-274.

SARTI, Cynthia. A vítima como figura contemporânea. Caderno $C R H$, vol. 24, n 61, Salvador, jan/abril, 2011, pp.51-61.

SODERBACK, F. Motherhood: A Site of Repression or Liberation? Kristeva and Butler on the Maternal Body. Studies in the Maternal, vol. 2, $\mathrm{n}^{\circ} 1$, 2010.

SouZA LiMA, Antonio Carlos. Apresentação Dossiê Fazendo Estado: O estudo antropológico das ações governamentais como parte dos processos de formação estatal. Revista de Antropologia, USP, vol. 55, $\mathrm{n}^{\circ} 2,2012$, pp.559-564.

VIANNA, Adriana; FARIAS, Juliana. A guerra das mães: dor e política em situações de violência institucional. cadernos pagu (37), CampinasSP, Núcleo de Estudos de Gênero-Pagu, 2011, pp.79-116.

- Violência, Estado e Gênero: considerações sobre corpos e corpus entrecruzados. In: SoUZA LIMA, Antônio Carlos de; GARCIAACOSTA, Virginia (org.). Margens da violência. Subsídios ao estudo do problema da violência nos contextos mexicanos e brasileiros. Brasília, ABA, 2014, pp.209-237.

; LOWENKRON, Laura. O duplo fazer do gênero e do Estado: interconexões, materialidades e linguagens. cadernos pagu (51), Campinas-SP, Núcleo de Estudos de Gênero-Pagu, 2017 [http://www.scielo.br/scielo.php?script=sci_arttext\&pid=S0104$83332017000300302 \& \operatorname{lng}=e n \& n r m=$ iso]. 